\title{
"ESPÍRITOS INDÍGENAS, MENSAGEIROS DOS ORIXÁS”: CRUZAMENTOS, PASSAGENS E CAMINHOS NA RELIGIÃO AFRO-BRASILEIRA
}

\author{
João Daniel Dorneles Ramos ${ }^{l}$
}

Resumo: Neste artigo, discuto os cruzamentos e as passagens que se dão na religião afro-brasileira partindo da relação entre espíritos indígenas e orixás. A interpenetração cosmos/sociopolítica e humano/extra-humano conecta práticas ameríndias e afro-brasileiras: o intermediário para o orixá que trabalha na pedreira será um(a) caboclo(a) da linha de Xangô. O Caboclo Sete Encruzilhadas - que abriu a religião para que os espíritos de pretos-velhos, de indígenas e de outros povos pudessem chegar - é intensivamente ligado a práticas rituais da Umbanda, da Quimbanda e do Batuque do Rio Grande do Sul, pois esse caboclo se cruza e pode atuar na terreira, em outra passagem sua, como Exu das Sete Encruzilhadas.

Palavras-chave: Religiôes Afro-Brasileiras; Devir; Caboclo Sete Encruzilhadas; Territórios Existenciais.

\begin{abstract}
In this article, I discuss the crossings and passages that occur in the Afro-Brazilian religion starting from the relation between indigenous spirits and Orishas. The cosmos/sociopolitical and human/extra-human interpenetration, connects Amerindian and Afro-Brazilian practices: the intermediary for the Orisha who works in the quarry will be a caboclo(a) of the Xangô line. The Caboclo Sete Encruzilhadas - that opened the religion so that the spirits of pretos-velhos, of indigenous and other peoples could arrive - is intensively linked to ritual practices of Umbanda, Quimbanda and Batuque of Rio Grande do Sul, because this caboclo crosses and can act on the terreira, in another passage of his, as Exu of the Sete Encruzilhadas.
\end{abstract}

Keywords: Afro-Brazilian Religions; Becoming; Caboclo Sete Encruzilhadas; Existential Territories.

1 Pós-doutorando (2017-) em Antropologia Social, Bolsa Jacques Gutwirth - PNPD Capes, pela Universidade Federal do Rio Grande do Sul, Porto Alegre, Brasil. E-mail: jodorneles@gmail.com.

Debates do NER, Porto Alegre, Ano i9, N. 36, P. 307-333, Ago./Dez. 20 i 9 


\section{INTRODUÇÃO ${ }^{2}$}

Para aquele que cruza as três linhas, a encruzilhada pertence ao exu - na gira; ao Bará - na nação; e ao Ogum, como orixá, como caboclo, como exu. A questão fundamental aqui é o jogo com as diferenças. Em lugar de uma identidade definida e precisa correspondendo ao nome de uma divindade, a linha cruzada apresenta uma multiplicidade para um nome-intensidade em metamorfose. (José Carlos dos Anjos, No território da linha cruzada)

A praia, a mata, a pedreira, o mar, a lagoa, a rua e muitos outros territórios e passagens ${ }^{3}$ constituem as práticas e relaçóes da Linha Cruzada - uma religião que agrega, no mínimo, três variaçóes ou linhas ${ }^{4}$ religiosas/ cosmo-ontológicas que a constituem: o Batuque ou a Nação (dos orixás), a Umbanda (dos caboclos, pretos-velhos e Ibejis) e a Quimbanda ou a Gira (dos exus, pombagiras, Povo Cigano e Povo do Oriente) (Anjos, 2006; Ávila, 2011; Barbosa Neto, 2012; Ramos, 2015a, 2015b; Oro, 1994).

Os cruzamentos da religiáo são feitos nos corpos e nos espaços físicos, realizados pelas entidades nas terreiras ${ }^{5}$ e envolvem, intensivamente, santos, orixás, caboclos, pretos-velhos, exus, pombagiras, ciganos, eguns e outras entidades do vasto panteão afrorreligioso. Uma linha da religião, como

2 Este texto apresenta algumas reflexôes oriundas de minha pesquisa de doutorado (2015a) e agrega discussóes realizadas na XI Reunión de Antropologia do Mercosur, ocorrida em Montevidéo, em dezembro de 2015. Agradeço os comentários feitos na ocasião por Marcio Goldman, Maria Belen Hirose e demais participantes do Grupo de Trabalho Teorias etnográficas da (contra)mestiçagem. Agradeço à Mãe Irma e Mãe Jalba, por todo aprendizado e convivência ao longo desse tempo e, ainda, à Josiane Wedig pela leitura atenta do texto, pelas críticas e sugestôes.

3 As palavras grafadas em itálico são noções, conceitos e termos êmicos.

4 Lado ou Linha são os termos êmicos para designar as variaçôes religiosas, rituais, existenciais etc. que compóem o vasto campo afrorreligioso.

5 Casa é outro termo para designar os templos. Também podem ser usados: Batuque, Ilê, Tenda, Terreiro etc. Utilizo no feminino, terreira, para concordar com a definição êmica, já que minhas interlocutoras a utilizam desse modo, constantemente. 
por exemplo a dos(as) pretos(as)-velhos(as), pode ser cruzada com práticas de saúde tradicionais quilombolas (benzeduras), com modos de existência ameríndios (caboclos e caboclas e seus pajés) e ser aliada a outras religiôes (sobretudo, ao espiritismo kardecista e ao catolicismo popular). Esse é o caso da Umbanda.

Os diversos territórios nos quais as religiōes afro-brasileiras operam são integrados às relaçóes entre humanos e outros entes, em diferentes momentos. Assim, cada linha da religiáo tem seus rituais e práticas independentes, que podem se cruzar com as formas e os modos de fazer e de existência de outros lados. Esses cruzamentos relacionam entes do cosmos como sujeitos ativos, que participam nas práticas de cura, nos trabalhos religiosos e espirituais, $\mathrm{e}$ no cotidiano das pessoas. Assim, distintos e intensos movimentos se dão pela conexão disjuntiva e de abertura para as diferenças que a religião produz, enquanto "jogo das diferenças" (Anjos, 2006).

Isso nos permite compreender outros modos de existência nos quais as ações rituais e cotidianas envolvem diferentes cosmo-ontologias e territorialidades, espaços físicos, elementos não visíveis, humanos, animais, plantas, pedras, entre outros. As diferenças podem ser conectadas, mas não são colocadas como unidade. Essa conectividade opera "em oposição ao pensamento arborescente que caracteriza a definiçáo de sincretismo (usual na definição das práticas religiosas africanas no Brasil)":

A ideologia da democracia racial fecundou toda uma imagem do Brasil como o país do sincretismo, da miscigenação racial. Para essa ideologia, a imagem do cruzamento das diferenças está mais próxima de certo modelo biológico, em que espécies diferentes se mesclam numa resultante que seria a síntese mulata. A religiosidade afro-brasileira tem um outro modelo para o encontro das diferenças, que é rizomática: a encruzilhada como ponto de encontro de diferentes caminhos que não se fundem numa unidade, mas seguem como pluralidades (Anjos, 2006, p. 21).

É nessas modalidades intensivas de aliança, agenciamentos territoriais e cósmicos que os cruzamentos, os caminhos e as passagens movem as diferenças.

Debates do NER, Porto Alegre, ano i9, N. 36, P. 307-333, Ago./Dez. 2019 
O que se expressa na religião são relaçôes entre humanos e entes diversos (extra-humanos), nas quais, conforme Anjos e Oro (2009, p. 90), as "coisas 'de outro mundo' destacam-se como o lugar da presença se puderem ser encadeadas à série preexistente, conformando um novo enunciado”. Partindo disso, os encadeamentos cosmo-ontológicos e os modos de existir das religióes afro-brasileiras são partes da cosmopolítica, ou seja, modulações e práticas de coexistência de (e entre) mundos, perspectivas nas quais há a irrupção do Cosmos na política (Stengers, 1997). A cosmopolítica não supõe a criação de um mundo comum, fechado, no qual teremos como fim último a integração ou a formação de uma unidade, de um consenso ou a fusão de sistemas. Ela é, sobretudo, a percepção de que mundos diversos, aliados e/ ou conflitantes, podem ser acionados e ligados em séries diferenciantes sem que se crie uma unidade de mundos e de práticas.

Atribuo, neste texto, a possibilidade de compreendermos as relaçóes entre humanos e extra-humanos, da e na religiāo, como momentos em que a "cosmopolítica afro-brasileira" (Anjos, 2006) opera. Em certo sentido, podemos asseverar a fecunda ideia aportada em Brito (2017, p. 175) de que, ao falarmos das religióes afro-brasileiras, estamos diante de uma "epistemologia", ao "revelar as conceptualizaçóes nativas acerca de alguns processos através dos quais o corpo da pessoa-médium”, nas diferentes modulações afrorreligiosas, "transforma-se em um instrumento para a materialização da presença dos guias espirituais". O autor, ao propor uma "abordagem epistêmica”, diz que, no "terreiro, as pessoas aprendem não só uma episteme, mas também uma epistemologia, a qual inclui técnicas de movimentação de energias e concepçóes gerais sobre os substratos ontológicos das coisas e dos seres" (Brito, 2017, p. 176) ${ }^{6}$.

6 Encontro ressonâncias entre o que o autor diz e as diversas reflexões que obtive, em minha etnografia, quando minhas interlocutoras mães de santo afirmam, enfatizando, que a religião é como uma medicina. Sobre isso, ver Ramos, 2015c.

Debates do NER, Porto Alegre, ano i9, N. 36, P. 307-333, Ago./Dez. 20 i9 
A encruzilhada não coloca os elementos que são cruzados na operação como soluçôes: eles se concretizam como perspectivas, caminhos e possibilidades que só serão atualizados enquanto regimes de existência se as forças evocadas e as práticas forem possíveis e fizerem sentido para a relação estabelecida. O "cruzamento de naçôes" que se opera na religião afro-brasileira "não é a imagem que normalmente se faz do sincretismo", pois essas naçôes "não são essências identitárias pertencentes a indivíduos, mas territórios simbólicos de intensidades diversas, passíveis de serem percorridos por multiplicidades de raças e indivíduos" (Anjos, 2006, p. 22).

Para ampliar esse entendimento sobre a encruzilhada, aciono a noção de devir (Deleuze; Guattari, 2007), compreendendo outros modos de relação e de existir, que não tomam o essencialismo identitário nem a formulação do uno como modelos. As diferenças se tocam, se cruzam e se afastam. Caboclos indígenas, entidades do povo da rua e orixás africanos são agregados de modo que as relaçóes e as mobilizaçôes de e entre múltiplos agentes no mundo ocorram. Os cruzamentos, as passagens e os caminhos nos indicam elementos-chave na compreensão de outros modos de existência nos quais ritual e cotidiano, sagrado e profano, humano e extra-humano envolvem e acionam diferentes perspectivas.

Este texto mobiliza reflexóes e práticas oriundas de etnografias realizadas $^{7}$ junto ao Centro Espírita Umbandista Reino d'Oxum e Ogum Beira Mar e Seguidores do Sete Encruzilhadas, que está situado na zona urbana do município de Mostardas (litoral médio do Rio Grande do Sul) e que conta com a participação - na corrente, na organização interna, religiosa e

7 A pesquisa que desenvolvi no doutorado (entre 2011-2015) foi possível a partir de questôes que surgiram durante a pesquisa de mestrado (realizada entre 2009-2011). Junto a quilombolas, obtive informaçóes de que havia, no centro do município de Mostardas, uma Casa de Umbanda, cuja máe de santo era uma mulher nascida naquela comunidade. Para outras informaçóes sobre essa comunidade quilombola e suas relaçóes com a religiosidade afro-brasileira, ver Ramos, 2015b.

Debates do NER, Porto Alegre, Ano i9, N. 36, P. 307-333, Ago./Dez. 20 i 9 
nas atividades abertas ao público (festas, homenagens, atendimentos, benzeduras, dia de terreira) - de diversas pessoas pertencentes a uma comunidade quilombola chamada Beco dos Colodianos.

A etnografia foi construída na minha participação em atividades nas terreiras e no convívio com umbandistas em diversos momentos, conversas etc. Experiências oníricas também foram importantes, pois o modo possível de afecção, nesse tipo de pesquisa, mobiliza uma outra perspectiva de atuação no mundo. Logo, o processo de pesquisa foi, e ainda se constitui como, uma espécie de artesanato, tendo havido uma lapidaçẫo constante do texto, das ideias e de mim mesmo.

$\mathrm{Na}$ terreira de Mãe Irma, há sempre uma primeira parte, que é identificada como Linha Branca, na qual chegam caboclos e, eventualmente, pretos-velhos e ibejis (espíritos de crianças). Há, ainda, uma segunda parte, tocando-se para a Linha do Povo da Rua, ou seja, para os exus, pombagiras e ciganos(as). No intermédio entre uma linha e outra, as pessoas da corrente trocam suas vestimentas (as da primeira parte são, geralmente, da cor branca, amarela, verde forte; nas da segunda, predominam as cores preto, vermelho e roxo). Essas duas linhas ou lados ocorrem em um mesmo terreiro e na mesma noite, operando-se intensidades que se conectam, se cruzam, mas que se mantêm em diferença. Não há unificação, nem das formas, nem das forças/intensidades.

A terreira, estabelecida junto à residência da mãe de santo, possui, aproximadamente, 30 anos de existência. Mãe Irma fez seu apronte no Batuque e demais reforços na religião com outra mãe de santo, Mãe Jalba, cuja terreira, o Ilê África Reino de Iansã e Xangô, Iemanjá e Bará e Seguidores do Sete Encruzilhadas, está localizada na cidade de Rio Grande, regiáo sul do estado.

8 O município de Mostardas é, em sua maioria, rural e possui três comunidades negras que pleiteiam o reconhecimento como quilombolas, todas oriundas da desagregaçáo do sistema escravista. Uma delas, a comunidade de Casca, já conseguiu a titulação do INCRA em 2010. As outras duas - a comunidade de Teixeiras e a do Beco dos Colodianos - ainda lutam para conquistar suas titulaçóes definitivas junto ao órgão federal responsável.

Debates do NER, Porto Alegre, ano i9, N. 36, P. 307-333, Ago./Dez. 20 i 9 
O reforço de Mãe Irma complementou, ainda mais, o seu aprontamento na religião e foi um processo no qual ela pôde ter o axé de búzios, também chamado de delegum, o que foi muito relevante para ela. A partir desse processo, essa mãe de santo pode jogar os búzios. Essas duas mães de santo são as principais interlocutoras da pesquisa que, não obstante, mobiliza outras vozes, de filhos(as) de santo de ambas.

\section{"CADA ORIXÁ TEM O SEU TERRITÓRIO E CADA UM TEM A SUA PASSAGEM": PERSPECTIVAS}

A potência de práticas ameríndias, como o xamanismo, pode ser levada em conta diante de intensidades, continuidades e descontinuidades que essas práticas operam e que são, de certa forma, atualizadas na Umbanda? Os(As) caboclos(as) são intermediários(as) de orixás e essas duas referências diferentes, a africana e a ameríndia, são conectadas sem precisar cair em uma unidade e nem em uma "idealização" essencialista do que é ameríndio ou do que é africano.

Cada intensidade é diferente e produz diferença. Neste item, pretendo traçar algumas relaçóes possíveis entre os elementos cosmo-ontológicos ameríndios e africanos que são cruzados constantemente pelas práticas umbandistas, considerando que podemos evocar o que Vanzolini (2014, p. 280), em outro contexto etnográfico, afirma:

Se os mundos do axé e os mundos perspectivistas apresentam dinâmicas comuns, isso não se deve à presença, em ambos, de uma força cósmica de natureza semelhante, nem resulta necessariamente da combinação entre dispositivos lógicos num dado contexto, mas advém do caráter intrinsecamente indeterminável do universo que esses dispositivos revelam.

As diferentes passagens, como lembra Barbosa Neto (2012), não querem dizer apenas as geraçôes que os orixás possuem, tampouco, simplesmente as formas que cada um(a) pode assumir. Elas são as possibilidades que um 
santo ou santa, orixás e outros existentes podem ter. O caboclo dá passagem, mas fica encostado, ele não abandona a pessoa por completo. Uma pessoa pronta suporta mais esse acontecimento de receber uma outra entidade que possui outras forças, energias diferentes. Ela faz a passagem. Isso é explicado no seguinte sentido: se Pai Xangô quer chegar e não tem uma pessoa naquela terreira que seja pronta, para que ele possa nela incorporar, ele chega e ganha passagem de outra entidade, para incorporar em uma pessoa. Ele pode, assim, trabalhar em um corpo e fazer o que precisa.

A entidade que teve passagem, podemos dizer que aumentou a sua potencialidade enquanto entidade da Umbanda, pois fez o trabalho que era necessário, para o qual havia sido incumbida e por meio do qual operou algo (uma cura ou limpeza) e o que precisava ser feito. É o caso da pessoa pronta, que pode receber várias entidades e até espíritos que estão buscando a luz (eguns). Como pontuam as mães de santo, somente as pessoas prontas e as pessoas com muitos anos de religião fazem isso, porque possuem força energética suficiente para tal.

Continuidades energéticas e determinadas forças atuantes, tendo os ameríndios como mediadores espirituais, são expressas no pensamento e nas práticas da religião afro-brasileira quando há a referência aos caboclos da Umbanda. Para Peixoto (2008, p. 27), os caboclos são:

[...] espíritos de índios brasileiros, sul ou norte-americanos, que dispóem de conhecimento milenar xamânico do uso de ervas para banhos de limpeza e chás para auxílio à cura das doenças. São entidades simples, diretas, por vezes altivas, como velhos índios guerreiros [...] São exímios na limpeza das carregadas auras humanas, experientes nas desobsessóes ${ }^{9}[. ..] \mathrm{Na}$ magia que

9 O autor indica como "desobsessão" a prática de retirada de espíritos chamados como obsessores, espíritos que operam forças negativas às pessoas e que precisam ser lapidados por espíritos de luz. Os caboclos sáo espíritos de luz que lapidam as pessoas e os espíritos. O xamanismo também opera algo nesse sentido: o xamã precisa mediar a saída dos espíritos dos animais abatidos antes de a comunidade consumir a carne da caça.

Debates do NeR, Porto Alegre, ano i9, N. 36, P. 307-333, Ago./Dez. 20 i9 
praticam, usam pembas para riscar seus pontos, fogo, essências cheirosas, flores, ervas, frutas, charutos e incenso.

Por sua vez, Paulo d'Ogum ${ }^{10}$ aponta que os caboclos eram caciques e que eles têm o conhecimento das ervas, da medicina. Isso nos mostra que a força indígena, enquanto fluxo energético, é operada como síntese disjuntiva - a conexão entre diferenças -, como uma abertura ao diferente. A Umbanda opera potências e vibraçóes cósmicas ligadas aos espíritos indígenas, que podem estar tanto na Amazônia como em uma pedreira, com grafismos, localizada no interior do município de Mostardas, como veremos. Então, os caboclos:

[...] são os espiritos indígenas, os mensageiros dos orixás. Porque os orixás não chegam na Umbanda, eles são da Nação Afro, então os caboclos são mensageiros dos orixás. A comunicação deles é espiritual: a pessoa faz um pedido para o caboclo e ele leva o pedido ao alcance do orixá. Eles fazem o intermédio (Entrevista com Paulo d'Ogum, Mostardas, dezembro de 2012).

A existência de práticas ameríndias atuando no interior da religião afro-brasileira permite compreender o entrosamento entre espíritos indígenas e os elementos afro-brasileiros. Segundo Sztutman (2009, p. 2),

[...] pessoas como os xamãs - ou pajés, se quisermos manter a palavra de origem tupi - podem ter acesso a essa humanidade dos [...] não-humanos, que se apresentam de variadas maneiras [...] Se xamãs são aqueles que podem, com mais facilidade, gerenciar seu próprio trânsito, eles são necessários, muitas vezes, para intervir nos trânsitos malsucedidos de seus congêneres. Não por acaso, muitas vezes foram referidos na literatura etnológica como mediadores, diplomatas, curadores ou mesmo médicos.

${ }^{10}$ Paulo d'Ogum é outro importante interlocutor da pesquisa, reside em Rio Grande. Algumas vezes, viajou a Mostardas para visitar a terreira de Mãe Irma, onde consegui conversar com ele.

Debates do NER, Porto Alegre, ano i9, N. 36, P. 307-333, Ago./Dez. 20 i 9 
O xamanismo ameríndio operaria em termos de uma política cósmica: os pajés são os "que administram as relaçôes dos humanos com o componente espiritual dos extra-humanos, capazes como são de assumir o ponto de vista desses seres e, principalmente, de voltar para contar a história" (Viveiros de Castro, 1996, p. 120). Entre os "mundos de axé" e os "perspectivistas" se traça não "apenas aquilo que a atividade ritual ou xamânica pressupóe, as 'participaçóes', mas também seu efeito para a afirmação de uma posição ativa do sujeito frente a outros (possíveis) sujeitos” (Vanzolini, 2014, p. 280).

Os processos de cura e de auxílio às pessoas ocorrem na religião e estão ligados, a meu ver, com o xamanismo indígena, à pajelança e também às relaçôes com a natureza que os diferentes coletivos não ocidentais operam. Seguindo Anjos (2006), acredito que esses elementos abrem possibilidades de outras formas de lidar com o sincretismo. As práticas afro-brasileiras vão além do, e contra o, conceito de "democracia racial", "sem cair no lusotropicalismo e nos mitos nacionalistas da mestiçagem cultural" 11 porque mostram que estamos diante de acontecimentos, devires e passagens, que são operados na lógica de "disjunção inclusa" (Deleuze, 2011), que é quando "cada ser implica de direito todos os seres", em um "processo [que] consiste em um percurso de intensidades” (Zourabichvili, 2004, p. 105-106).

No caso pesquisado, opera-se uma relação cosmopolítica quando os afrorreligiosos evocam a importância dos caboclos indígenas e pajés, que realizam curas e estabelecem relaçóes com os espíritos auxiliares: os animais e as plantas. Essas relaçôes são feitas e se dão em territórios nos quais a mediação não só será possível como é intensivamente necessária, como na atuação com as práticas de cura e as receitas de banhos de ervas. A interpenetração do cosmos e dos corpos permite aprender a operação de relações: o intermediário para o orixá que trabalha na pedreira será algum caboclo da linha de Xangô na Umbanda. Essa relação é explicada por Cristian ${ }^{12}$ :

${ }^{11}$ Declaração de José Carlos dos Anjos em conversa com o autor deste artigo (2012).

12 Cristian é outro importante interlocutor, reside em Rio Grande e integra a terreira de Mãe Jalba. 
Se a filha [carnal] da Mãe Irma for à beira da praia fazer um serviço, não vai ser a Jurema dela, das Matas, quem vai chegar [incorporar] nela; quem vai chegar é a Jurema da Beira da Praia. Se ela estiver numa pedreira, quem vai chegar é a Jurema da Pedreira, de Himalaia, que é a Jurema que eu trabalho, e não a Jurema das Matas. Isso depende do território! Cada Orixá tem o seu território e cada um tem a sua passagem! Pelo lado de Umbanda, existem sete Orixás: Bará, Ogum, Iansã, Xangô, Oxum, Iemanjá e Oxalá. Quando eu falo Bará, ele não fica restrito só a um Bará, entendesse? Este Bará, que eu falo, para o lado da Umbanda, puxa o Xapanã para a linha dele. E, tem um monte de caboclos que são Oguns. São vinte e sete Oguns e, destes, saem os caboclos. Cada orixá tem seus caboclos, vários, mulheres e homens (Entrevista com Cristian, Rio Grande, agosto de 2012).

Cristian salienta a relação entre os orixás, caboclos e os territórios nos quais os trabalhos são realizados: se o serviço ocorrer em uma pedreira, a pessoa vai receber uma cabocla Jurema que vem na linha de Xangô; se for à beira da praia, uma Jurema da Beira da Praia, cabocla da linha de Iemanjá. Assim, é nas intensidades, nas passagens e nas forças energéticas que os territórios e os corpos operam porque os orixás estão no local da evocação da intermediação: o orixá da pedreira é o Xangô; da praia de água salgada, é Iemanjá; da mata, é Ogum. Os diferentes caboclos e caboclas vão operar os trabalhos e a intermediação entre humanos e extra-humanos. Do mesmo modo, na terreira, cada ponto chama uma linha específica de cada orixá e dos caboclos a ele associados. No ponto de Ogum, por exemplo, vão chegar (incorporar) nas pessoas, caboclos da linha de Ogum.

Quando a pessoa já está bastante lapidada, ou seja, já passou por determinadas fases de aprontamento e participação na religião, ela incorpora um caboclo e fica com esse até o final da Linha Branca ou pode dar passagem para outro caboclo de outras linhas que os pontos vão chamando. Já as pessoas que ainda estão se desenvolvendo na religião recebem uma entidade no momento ritual e desincorporam antes de darem o passe $e^{13}$ nas pessoas

13 O passe é uma forma de limpeza energética-corporal, durante o qual a entidade de luz realiza alguns movimentos junto ao corpo da pessoa que está sendo atendida. Mesmo

Debates do NER, Porto Alegre, Ano i9, N. 36, P. 307-333, Ago./Dez. 20 i9 
e ficam, enquanto cambonos $^{14}$, no auxílio das pessoas que vão ter com as entidades que estão na terra.

Sem os intermediários - os diversos espíritos e as diferentes energias -, a religião não realiza a sua potência. A Linha Cruzada conecta as diferenças não para formar uma unidade, mas para manter as diferenças intensivas, enquanto tais: nada se faz sozinho e nada opera pelo uno, há as ligações e há os distanciamentos possíveis. O cruzamento possibilita que em uma pedreira dos indios possa ser feito trabalho para Xangô.

Certa vez, quando conversávamos, Mãe Irma e o seu ex-companheiro me falaram da existência de um local, no interior do município de Mostardas, no qual havia gravuras indigenas em pedras (grafismos rupestres, em um sítio chamado Taroca, localizado no Rincão, à beira da Lagoa dos Patos). Na perspectiva da Umbanda, esse local é intensamente forte nas relaçóes que a religião opera. Quando se evoca aquela pedreira como um lugar importante para as práticas religiosas, realiza-se um encadeamento cósmico, uma conexão coexistente de diferenças, atualizando intensidades possíveis de serem compostas em suas relaçóes.

O Xangô trabalha na pedreira e tem como aliados os caboclos, que possuem práticas indígenas milenares. Na pedreira do Rincão, segundo as pessoas da terreira, havia os pajés, os preservadores da religiāo, os feiticeiros, como foi dito na conversa que tivemos. Essas forças podem ser acionadas na terreira e em outros momentos - como em um atendimento, quando o

que essa não apresente nenhum problema de saúde visível, todos os presentes nas atividades da religiáo, que são abertas ao público, como as homenagens aos santos ou os dias de desenvolvimento de membros da corrente, recebem o passe como forma de cura, proteção e contato com as entidades. É uma característica da linha de Umbanda e da linha dos pretos-velhos. Nos casos aqui tratados, as pessoas que desejam receber o passe das entidades são informadas do momento pela cabocla-chefe e se dirigem até elas, que esperam no centro do salão da terreira.

${ }^{14}$ Membro da corrente, auxiliar da mãe ou pai de santo da Casa, e das entidades. Responsável por informar as pessoas e passar as receitas que as entidades indicam para aqueles com quem conversaram ou em quem deram passes. 
caboclo ou a cabocla possuem a força de curar, mesma força que tem um pajé, porque ele tem o conhecimento das ervas, da medicina.

Conhecer a força dos indios é a parte da aprendizagem que a pessoa opera na religiosidade afro-brasileira: ela não pode e não deve conhecer sem ter a vivência na e da religião, a percepção da natureza e de tudo aquilo que envolve seu corpo, seu espírito e suas relaçóes com os orixás, com substâncias, com outras entidades, com animais, com plantas, com o Cosmos. É pela vivência, pelo entrosamento ritual e cotidiano entre humanos e extra-humanos, que a pessoa vai conhecer mais e saber como fazer (n)a religião.

Tais circunstâncias são constantemente evocadas no conceito de lapidação, no desenvolvimento do espírito e do corpo batuqueiro (Anjos, 1995). A pessoa, nas religiōes afro-brasileiras, passará por apreensão de substâncias, que construirão e constituirão seu corpo, por relaçóes entre ela e outros entes, podendo chegar ao grau de Máe ou Pai de Santo, iniciando outras pessoas na religião, abrindo sua própria terreira, realizando atendimentos, jogando os búzios, fazendo benzimentos etc.

Os caboclos indígenas são intermediários de orixás africanos, são Mensageiros. Essas duas referências diferentes, a africana e a ameríndia, são conectadas, sem formar unidade e nem "idealização" essencialista do que é ameríndio ou do que é africano. Cada intensidade é diferente e produz diferenças. O Sete Encruzilhadas, como veremos, cruza-se: ele é caboclo da Umbanda, mas poderá chegar ao Batuque, porque, segundo Mãe Jalba, ele já é quase orixá e, ainda, já chega como exu, na Linha de Exu, na virada que ele faz. Aqui, outro elemento de diferenciação ocorre: a possibilidade de um caboclo indígena assumir uma posição no panteão de orixás africanos, sem dividir essas potências de forma estanque. Pois, na virada que ele faz, ele se nomadiza entre diferentes linhas de atuação: Umbanda, Quimbanda, Batuque...

Há, portanto, um intensivo encadeamento de conhecimentos ameríndios e africanos a partir da intermediação e das práticas que se operam na Umbanda. No que envolve a cura, umbandistas afirmam que a religiāo é uma medicina. Em diversos textos umbandistas e no que as máes de santo 
e outras pessoas evocam, encontramos a ideia de que a Umbanda é mais que religião, é ciência. A própria palavra "Umbanda" - que, segundo vários estudos, é oriunda do kimbundu, uma das diversas línguas africanas - quer dizer "arte de cura" 15 . Isso a aproxima, de certa forma, da práxis cosmo-ontológica dos pajés, no sentido literal, o que também se conecta ao que afirma Vanzolini (2014, p. 276): o "axé orienta as religióes de matriz africana para o desenvolvimento de mecanismos de controle das conexôes entre os diversos elementos e partes do cosmo, em um regime comparável àquele em que, entre povos indígenas da América do Sul, se dão as transformaçóes xamânicas”.

Estamos diante de coletivos sociocósmicos, nos quais os processos de cura só podem estar ligados a outros elementos, como as entidades, os animais, as plantas etc., em uma interação constante. Conforme Sztutman (2009, p. 4) enfatiza, os povos ameríndios "estariam acostumados a conceber o que chamamos de natureza como um domínio fortemente dependente da ação humana, em interação constante com o domínio humano”.

Para afrorreligiosos(as), a meu ver, a "natureza" é também permeada por diversos entes partícipes dela, sendo permeada pelas relaçóes humanas e extra-humanas, em interação constante e diferenciante. $O$ peso que essa dimensão possui se dá em termos de cruzamentos possíveis, entre diversos modos de existência e nas práticas de cura e saúde. Não se trata apenas de um "cuidado" com a natureza, mas sim de uma relação intensiva entre Cosmos, pessoas e outros entes, operada em um plano de coexistência em que a natureza (a mata) é conectada a outras dimensôes ${ }^{16}$. O acontecimento de cruzar corpos, entidades e locais, curar pessoas e realizar sacrifícios ${ }^{17}$ aos orixás e a outras entidades opera práticas de coexistência entre possíveis.

${ }^{15}$ Ao afirmar que praticantes da Linha Cruzada se reconhecem como umbandistas ou chamam a religiáo de Umbanda, vemos que eles e elas operam a arte de curar com tal reconhecimento - a palavra é potência.

${ }^{16}$ Sobre isso, ver Cabrera (2012), no contexto afrorreligioso cubano.

${ }^{17}$ Sobre o sacrifício de animais, neste contexto de pesquisa, ver Ramos, 2016. 


\title{
“SEU SETE ENCRUZILHADAS”, CABOCLO E EXU
}

\author{
Roda Sete Encruzilhadas, \\ Na sua Linha de Bará. \\ Ele comanda a sua terreira, \\ Louvado seja em nome de Oxalá! \\ Saravá meu pai, \\ No reino da Oxum, \\ Ele que é o nosso chefe, \\ A segurança do Congá.!'
}

O Caboclo Sete Encruzilhadas abre a religião para que os espíritos de negros escravizados, de indígenas e de outros povos possam chegar. Em textos umbandistas e sobre a Umbanda, aponta-se como acontecimento fundador dessa religião a incorporação de um espírito indígena por Zélio de Moraes: ele recebeu o Caboclo das Sete Encruzilhadas em uma sessão espírita no Rio de Janeiro, em $1908^{19}$. Esse acontecimento marca a abertura e propagação dessa religião, abertura também às linhas, aos povos e suas potências, podendo realizar curas e caridade.

Essa propagação da Umbanda, atualizada pelo Sete Encruzilhadas, está baseada na concepção de que essa religião existe há milênios, de que ela é uma das religióes mais antigas do mundo e que possui ligaçóes com o Egito Antigo, com a Índia e com o Oriente ${ }^{20}$. Segundo Peixoto (2008, p. 23), a Umbanda é caracterizada como um "movimento caritativo mediúnico de

${ }^{18}$ Ponto cantado na terreira de Mãe Irma. Noto, aqui, que o nome das duas terreiras possui o "Seguidores do Sete Encruzilhadas". Por isso, sempre começam as atividades da terreira com o ponto de abertura dos trabalhos e, após, vem esse ponto do Sete Encruzilhadas. Nos casos em questáo, troca-se o trecho do ponto, se esse é cantado ou tocado no reino da Oxum (Casa da Mãe Irma) ou no reino da Iansã (Casa de Mãe Jalba).

${ }^{19}$ Ver Giumbelli (2002) e Peixoto (2008).

${ }^{20}$ Mãe Jalba me falou, certa vez: Tu vens procurar o que tem de afro na religiäo? Mas tens que ver que ela [a religião] é muito mais antiga! Isso vem lá da India e do Egito Antigo! 
inclusão espiritual [...]. A natureza cósmica não é rígida e imutável, e sim flexível e em constante transformação".

Paulo d'Ogum enfatiza que o surgimento da Umbanda foi um modo de abrir muitas portas, para todas as entidades que não tinham como chegar [não tinham entrada no espiritismo]. O Sete Encruzilhadas fundou a Umbanda e ele abriu portas para todo mundo! Todos os povos! Porque na Umbanda entra qualquer linha, pois cada linha tem seu comandante e tem uma porta para passar, para entrar e sair. Ele ainda declara sobre Seu Sete Encruzilhadas:

Quebrou aquele preconceito, não é!? [de os espíritas não deixarem as entidades negras e indígenas atuarem nas sessóes mediúnicas]. Era um preconceito isso aí! E, outra coisa, os pretos-velhos, os espiritos dos negros africanos, não tinham onde chegar, porque na religião africana, no Candomblé, eles eram considerados sofredores. Então, teve um espaço, uma porta aberta na Umbanda para os negros africanos chegarem. Assim, comę̧ou a chegar a Linha dos Pretos-Velhos e é infinita a quantidade deles. Eeles têm uma 'baita'sabedoria (Entrevista com Paulo d'Ogum, Mostardas, 7 de dezembro de 2012).

Essa abertura feita pelo Sete Encruzilhadas realiza um encadeamento no qual espíritos tidos como "atrasados" e "sofredores" possuem suas intensidades energéticas e podem fazer curas. Paulo d'Ogum ainda explica que o Caboclo Sete Encruzilhadas,

[...] chegou dentro do kardecismo e eles [kardecistas] não aceitaram! Deste modo, o Caboclo Sete Encruzilhadas ordenou que juntassem um povo e fizessem a Umbanda e ela começou só na palma da mão, sem tambores. O tambor foi adaptado da Nação Afro. Era só na palma da mão e todo mundo vestido de branquinho. E começou a chegar os caboclos, indios, nesta religiāo. Eles chegavam um pouco crus, uns falando Tupi-guarani ou com linguagens que ninguém entendia. Com o passar do tempo, os indios foram se lapidando e conseguiram se entrosar e serem entendidos, mas o Sete Encruzilhadas, como Caboclo chefe, entendia tudo (Entrevista com Paulo d'Ogum, Mostardas, 7 de dezembro de 2012). 
O lapidar é o movimento constante por meio do qual se aprontam espíritos, humanos, corpos, pedras etc., para que haja conexão com os outros entes do Cosmos. Quando é evocado que os espíritos - nesse caso, os ameríndios - foram se lapidando, estamos diante de uma noção que envolve tanto o sentido de agregação (conseguiram se entrosar) como também o próprio conceito de aprontamento, iniciação na religião, já que também os espíritos vão apreendendo elementos, formas e forças, junto aos humanos. $\mathrm{O}$ fundamento, portanto, sempre opera, nas religióes de matriz africana, como elemento ligado ao processo de feitura - seja esse de uma pessoa, de uma entidade ou de um outro modo de existir. $\mathrm{O}$ fundamento tem a ver com o criar e recriar procedimentos, e o aprontamento é um dos elementos-chave e compósitos do fundamento.

Os espíritos, desse modo, vão sendo aprontados, assim como também a pedra e a pessoa são aprontadas no Batuque ${ }^{21}$. Ao mesmo tempo, quando Paulo d'Ogum menciona que chegavam os indios, vemos que ele aciona a ideia de que os espíritos ameríndios andam juntos com as forças de orixás e de outros entes relacionais afro-brasileiros (pretos-velhos, exus, pombagiras etc.). Assim, a partir de uma lapidação, a própria linha de Caboclos vai assentando-se na terreira e nas formas cosmo-ontológicas de atuação na religiosidade.

Na bibliografia umbandista, Peixoto (2008, p. 15-16) afirma que Zélio de Moraes, aos dezessete anos, "começou a sofrer estranhos surtos, durante os quais se transfigurava totalmente", tomando postura de "um idoso, com sotaque diferente e tom manso, como se fosse uma pessoa que tivesse vivido em outra época" ou, ainda, "tomando uma forma que mais parecia a de um felino lépido e desembaraçado que mostrava conhecer muitas coisas

${ }^{21}$ As pedras são, no Batuque, os acutás, que possuem as forças dos orixás. Cada orixá tem uma pedra (acutá) de tamanho, cor e formatos diferentes. Conforme Anjos (2008, p. 89), o "acutá não remete para um poder que do além se faz representar num mediador simbólico. $\mathrm{O}$ acutá - essa pedra sagrada aqui e agora - já carrega de imediato a totalidade do ser da divindade. Esta pedra sagrada, aqui e agora, é o Xangô, o Ogum, a Iemanjá”.

Debates do NER, Porto Alegre, ano i9, N. 36, P. 307-333, Ago./Dez. 20 i 9 
da natureza”. De minha parte, vejo que, por essa descrição, Zélio já estava apreendendo potências oriundas de outras intensidades, antes mesmo da incorporação realizada pelo Sete Encruzilhadas, durante uma sessão espírita.

Os "estranhos surtos" que o "transfiguravam" fizeram com que seu pai o levasse à Federação Espírita de Niterói. Na ocasiáo, segundo Peixoto (2008), manifestaram-se entidades de africanos escravizados e indígenas nos presentes. O dirigente da Federação achou aquilo um absurdo e alegou que essas forças eram "atrasadas espiritualmente". $\mathrm{O}$ autor conta que Zélio foi entâo tomado por uma força estranha e que disse: "'Por que repelem a presença desses espíritos, se nem sequer se dignaram a ouvir suas mensagens? É por causa de suas origens e de sua cor?’”. Ao ser questionado a respeito de que força era aquela que tomava Zélio, ela respondeu que era o Caboclo das Sete Encruzilhadas ${ }^{22}$, "pois, para mim, não haverá caminhos fechados":

[...] a entidade revelou a missão que trazia do Astral: "Se julgam atrasados os espíritos de pretos e índios, devo dizer que amanhã ( 16 de novembro) estarei na casa de meu aparelho, às 20 horas, para dar início a um culto em que esses irmãos poderão transmitir suas mensagens e cumprir a missão que o plano espiritual lhes confiou. Será uma religião que falará aos humildes, simbolizando a igualdade que deve haver entre todos, encarnados e desencarnados" (Peixoto, 2008, p. 17).

Em outro sentido, Giumbelli (2002, p. 194), ao falar de Zélio, pontua uma série de autores e autoras que se debruçaram a explicar o "surgimento" da Umbanda no Brasil. Algumas explicaçóes colocavam Zélio como "pioneiro" ou como "veículo" de "propagação da Umbanda", e outras nem mencionavam seu nome. Para o autor, "mesmo os textos que tratam das origens ou da história da Umbanda, ou mesmo do Caboclo Sete Encruzilhadas

${ }^{22}$ Peixoto (2008, p. 16-17) explica que o espírito havia falado que era, no momento, “'resquícios de uma encarnação em que fui o padre Gabriel Malagrida. Acusado de bruxaria, fui sacrificado na fogueira da Inquisição... Mas, em minha última existência física, Deus me deu o privilégio de reencarnar como um caboclo brasileiro"”.

Debates do NER, Porto Alegre, ano i9, N. 36, P. 307-333, Ago./Dez. 20 i 9 
[...] não se sentem obrigados a mencionar o nome de Zélio”. O autor reconhece que "o problema das origens da Umbanda não pode ser reduzido a questóes de prioridades e de fundadores", uma vez que "não faz muito sentido procurar por prioridades e fundadores em um processo que em boa medida ocorreu, por assim dizer, rizomaticamente, sem direção única e sem controle centralizado".

Considero que é no acontecimento de abertura da Umbanda que o espiritismo kardecista também se abre para outras entidades (antes repelidas), como os pretos-velhos e os indígenas. É por esse processo que abre caminhos diferenciantes, que vemos os cruzamentos enquanto encadeamentos, como modos criativos de regimes de existência, nos quais se processam aberturas e fechamentos. É o caso da Linha Cruzada: Mãe Jalba, que recebe o Seu Sete Encruzilhadas, enfatiza que alguns caboclos podem chegar na linha dos Exus. Ela fala sobre as passagens, mencionando um ponto que diz: "Sete Encruzilhadas, Santo Antônio ele é". Entâo, ele tem uma passagem. E o Santo Antônio, no cruzamento, é o Bará jovem!

Diversas vezes vi Seu Sete Encruzilhadas praticar cruzamentos na religião. Certa vez, em maio de 2012, quando começavam os preparativos para se realizarem os sacrifícios e outras práticas rituais para efetivar o reforço de Mãe Irma no Batuque, em Rio Grande, na terreira de Mãe Jalba, uma das filhas de santo da Casa perguntou: Mãe Jalba, a senhora me dá licença para acender uma vela para o Seu Sete? Como resposta, ela disse: eu ia acender, $e$ me esqueci! Pode sim! Assim, esta senhora colocou em frente à imagem do Sete Encruzilhadas uma vela acesa.

Em um ritual destinado ao Batuque, o Sete Encruzilhadas foi aliançado: a relação com ele estava sendo efetuada junto com a relação com orixás, desde o início, mas teve de ser confirmada acendendo-se uma vela, na terreira, para ele. Se tudo se inicia com exu, com Bará, e o Caboclo Sete Encruzilhadas se cruza como exu, ele precisou ser agregado ao que estava sendo feito, antes de começar os sacrifícios. Como vimos, os caboclos são mensageiros dos Orixás. 
O segundo fato aconteceu em agosto de 2012, na homenagem realizada para Seu Sete Encruzilhadas, na linha de Umbanda, também na Casa de Mãe Jalba. Em determinado momento, o próprio caboclo puxa um ponto no qual mencionava que ele era Exu. O ponto, que eu já ouvira em outras oportunidades, inclusive cantado por pombagiras, dizia: Se ele ganhou esse presentel Éporque ele é o Exu. Ele, lhe agradecel Muito obrigado, na Lei de Exu. Após o Sete Encruzilhadas puxar esse ponto, falou: se a terreira é cruzada, tem que puxar o ponto de Exu! Ele puxou esse ponto no momento em que caboclas e caboclos dançavam com uma torta ${ }^{23}$, indo do centro do saláo da terreira até a porta de entrada do templo, que ficara aberta o tempo todo. Naquela noite, de Festa de Caboclo, o Seu Sete puxou o ponto de Exu ${ }^{24}$. Mãe Jalba explica como o Sete Encruzilhadas tem a sua virada para Exu:

Existem três passagens do Seu Sete: da mocidade dele à velhice! São as passagens, o tempo dele ${ }^{25}$. Seu Sete cruza as linhas porque ele é o indio mais velho. O primeiro protetor que veio na terra. Ele tem escada para subir, vai evoluindo e passa pela

${ }^{23}$ Esse momento ritual ocorre em todas as homenagens realizadas, em ambas terreiras, pela linha de Umbanda e, na homenagem feita para Exus e Pombagiras. Trata-se de um percurso no qual as entidades que estáo na terra, ou seja, incorporadas, equilibram uma torta (similar às que são feitas para festas de aniversário) no topo da cabeça e dançam percorrendo o salão da terreira, dirigindo-se, geralmente, do congá (altar) até a porta do templo. Cada entidade passa a torta para uma outra, que faz o mesmo percurso. Nos casos de homenagens para santos, é cantado o ponto correspondente como, por exemplo, para Oxum, canta-se: "Eu vi mamãe Oxum na cachoeira, sentada na beira do rio. Colhendo lírio lírio ê, colhendo lírio lírio ah, colhendo lírio pra enfeitar o seu Congá”.

${ }^{24}$ Cristian também ressalta que o Sete Encruzilhadas chega pelas Sete Linhas! Que ele trabalha em qualquer linha.

25 A dimensão de passagens ocorre em relação a Orixás: por exemplo, existem as passagens criança, adulto e velho do Oxalá, da Iemanjá, do Ogum... Em outros lugares e contextos chamam-se qualidades. Já a virada opera algo complexo em que a entidade pode, então, cruzar as linhas ou lados afrorreligiosos, assumindo características de outros povos, atuando com outras forças mas, não obstante, produzindo axé.

Debates do NER, Porto Alegre, ano i9, N. 36, P. 307-333, Ago./Dez. 20 i 9 
Linha do Povo da Rua. Ele comanda a tribo dele toda! A bandeja dele [oferenda] é caça, mas a gente não pode caçar para dar para ele! Vinho, até hoje não sei porque, é a bebida dele, porque antes era cerveja preta... Ele deu uma virada e hoje é vinho! É, ele fez muita virada! Ele é uma tribo [...]. A virada dele é um segredo e foi quando ele veio, por primeiro, é que começou a Umbanda. Com muitas dificuldades: era tudo feito sem tambor, escondido e com luz apagada!! Era tudo à luz de velas, porque não se acendia a luz para as pessoas de fora não verem! Era tudo escondido na época, se não, vinha a policia e prendia todo mundo! Mas o Seu Sete, quando vem, traz toda a tribo dele (Entrevista com Mãe Jalba, Mostardas, dezembro de 2013).

Nessas aberturas, se os entes são encadeados ou cruzados no processo, é porque eles fazem parte para que isso funcione; eles são confrontados, ligados e dispersados enquanto forças possíveis de atuação. E, nessas forças, existem as viradas. Mãe Jalba afirma que, no mundo dos Orixás e dos Caboclos, há uma irmandade, sem entes superiores:

Eu venho trabalhando com Seu Sete há muitos e muitos anos e ele faz muita coisa! Quando estou na pior, grito para o Seu Sete. Ainda, ele faz virada para o Exu. Ele trabalha na Linha de Exu! Ele cruza e ele se cruza! É porque o Exu das Sete Encruzilhadas é o mesmo que o Seu Sete Encruzilhadas [caboclo], mas ele faz virada, quer dizer, ele tem luz suficiente para isso! Chega na terreira [umbanda] e chega na Linha dos Exus. Ele tem a permissão para isso. E, no momento que ele for considerado um Orixá, ele já não faz mais isso, pois virá o sucessor dele e ele vai para o Batuque, como Orixá (Entrevista com Mãe Jalba, Mostardas, dezembro de 2013).

Se a Casa é cruzada, consequentemente, a chefe da terreira e outras pessoas (e entidades) também são: Mãe Jalba tem como seu caboclo o Sete Encruzilhadas, mas que chega também em outra linha, ele é cruzado com o exu, ele faz a abertura para a Linha de Exus. Essa abertura ele já fez também quando chegou ao espiritismo kardecista, quando abriu a Umbanda, para que espíritos de negros escravizados e de ameríndios pudessem chegar. Para Mãe Jalba, o Seu Sete é um caboclo, que ainda não está considerado, mas é 
quase um Orixá! Se ele vier numa Linha de Nação, numa Roda de Batuque, ninguém diz que ele é um Caboclo!

Quando o Sete Encruzilhadas se cruza, na virada, ele opera um devir-exu do índio ${ }^{26} \mathrm{~A}$ partir de um devir-orixá, o que as máes de santo operam e encadeiam é uma aliança intensiva ${ }^{27}$, porque isso envolve o Cosmos e diferentes entes, ativando a potência de um(a) orixá no território em que ele ou ela trabalham. Assim, quando a máe de santo faz o cruzamento, no momento de iniciar uma pessoa na religiáo, ativa, consequentemente, uma série de outros actantes que são espíritos mediadores (da Umbanda, Quimbanda e do Batuque) e que, também, são potencialmente fortes.

\section{POR UMA CARTOGRAFIA DA “COSMOPOLÍTICA AFRO-BRASILEIRA"}

A abertura e as conectividades na religião são o cruzamento e as passagens. É por meio da diplomacia cósmica de (e entre) mundos e entes que o encadeamento cósmico ocorre:

A "abertura de caminhos" também passa pelos cruzeiros, aqueles em cruz $(+)$ ou num xis (x). Abrir os caminhos significa aliviar os percursos de um empreendimento de possíveis interferências negativas. Os empreendimentos da vida também são percebidos como caminhos: realizar-se profissionalmente, ter sucesso escolar, fazer um bom casamento. As linhas de vida devem ser mantidas livres de obstrução espiritual. Muito além de uma simples metáfora entre a vida e os caminhos, temos, creio eu, um pensamento que faz da vida um território (Anjos, 2006, p. 19).

${ }^{26}$ Certa vez, quando conversávamos na terreira de Mãe Jalba, Cristian me disse que a forma dos exus e das pombagiras pode ser de indios e indias. Segundo ele, na Africa, tem os negros, mas também tem tribos de indios. Então, existem exus que são indios.

${ }^{27}$ Ver Viveiros de Castro, 2007. 
Estaríamos diante de um devir-orixá do caboclo, de um devir-índio do exu, de um devir-negro de Santo Antônio? Os caminhos só são possíveis se houver o encadeamento com diversos entes, relacionando-os. Vimos que há os intermediários, que são caboclos e caboclas, e que há as passagens; e há, ainda, fluxos e energias que operam cruzamentos nos corpos, nas Casas, nos territórios e no Cosmos.

Danowski e Viveiros de Castro (2014, p. 93), ao falarem dos povos ameríndios, dizem que, para esses, o mundo é "uma multiplicidade de multiplicidades intrincadamente conectadas”. De minha parte, considero que, para o caso dos grupos afro-brasileiros e, notadamente, afrorreligiosos, acontece algo muito similar: em suas práticas cotidianas e rituais, estão constantemente envolvidos os elementos da natureza e da cultura, imbricados em práticas cosmopolíticas, nas quais uma miríade de potências, entes e forças atuam. Assim, "[...] os ameríndios pensam que há muito mais sociedades (e, portanto, humanos) entre o céu e a terra do que sonham nossas antropologias e filosofias. O que chamamos de 'ambiente' é para eles uma sociedade de sociedades, uma arena internacional, uma cosmopoliteia" (Danowski; Viveiros de Castro, 2014, p. 94, grifo dos autores).

Corroboro Vanzolini (2014, p. 280) quando a autora indica que "tanto nos mundos indígenas quanto no universo das religiôes de matriz africana no Brasil, é preciso afirmar-se sujeito em um universo povoado por outros sujeitos, ou afirmar sua força em um universo povoado de outras forças - isto é, outros sujeitos e outras forças [...]”. É que para os coletivos afro-brasileiros e para os coletivos indígenas, estamos diante de modos de existência complexos, nos quais uma série de elementos estão intrinsecamente imbricados na (quase) dissociação entre natureza e cultura e que são, notadamente, povoados por diversos entes.

E, ressoando elementos da filosofia grega antiga ao propósito deste texto, concordo com Spinelli (2006, p. 42, grifos do autor) que, "[s]e tivéssemos que restringir a palavra kósmos a um único termo, arranjo seria certamente o que melhor lhe conviria, em razão de sua amplitude e sua variação de significados...". Segundo essa premissa, o que chamamos de Cosmo é um 
constante "arranjo" de "modos diferentes" (Spinelli, 2006, p. 43) e, refletindo sobre a religiosidade afro-brasileira, podemos dizer que este arranjo cósmico se dá tanto pela interação dos diferentes entes em contato como, também, pelas práticas rituais constantemente desenvolvidas nos terreiros.

Assim, podemos considerar a existência de um devir-outro, um devir -raça, um devir-povo quando são evocados os cruzamentos das linhas nesse modo de existir que produz diferenças nas relaçóes e que não toma a unidade como modelo, produzindo as diferenciaçóes possíveis, em um arranjo. Agenciamentos e devires operam-se em modos de existência porque, justamente, não são da ordem da semelhança, nem da imitação, nem da identidade. Segundo Deleuze e Guattari (2007), as relaçóes que compóem, decompóem ou modificam um indivíduo correspondem a intensidades que o afetam, aumentando ou diminuindo sua potência de agir, vindo das partes exteriores ou de suas próprias partes.

É quando um caboclo faz as curas de um pajé indígena na Umbanda e, na virada, faz a intermediaçẫo entre as pessoas e as divindades, como exu, que as entidades produzem e operam suas relaçôes e fazem cosmopolítica, conectando territórios, corpos e agenciamentos extra-humanos. Em uma benzedura, um banho de ervas, uma proteção estáo sendo agenciadas potências, forças cósmicas, natureza, pessoas, locais, acontecimentos. As relaçôes se constituem nos caminhos percorridos e traçados pela religiáo afro-brasileira.

Nas religiôes de matriz africana, portanto, não temos uma "síntese mulata", mas a encruzilhada e é nessa que se opera a cosmopolítica afro-brasileira (Anjos, 2006). Nesse território existencial - que pertence ao Bará, ao Exu e à Pombagira e também ao Ogum, orixá intensivamente ligado às matas dos indios -, é que a Umbanda, o Batuque, a Quimbanda e outras formas cosmo-ontológicas e afrorreligiosas são afetadas por diferentes agenciamentos, arranjos cósmicos e potências. 


\section{REFERÊNCIAS}

ANJOS, José Carlos Gomes dos. A filosofia política da religiosidade afro-brasileira como patrimônio cultural africano. Debates do NER, Porto Alegre, ano 9, n. 13, p. 77-96, 2008.

ANJOS, José Carlos Gomes dos. A iconoclastia afro-brasileira na Festa de Nossa Senhora dos Navegantes em Porto Alegre. In: ENCONTRO ANUAL DA ANPOCS, 33., 2009, Caxambu. Anais [...]. São Paulo: ANPOCS, 2012.

ANJOS, José Carlos Gomes dos. No território da linha cruzada: a cosmopolítica afro-brasileira. Porto Alegre: Editora da UFRGS, 2006.

ANJOS, José Carlos Gomes dos. O corpo nos rituais de iniciação do batuque. In: LEAL, Ondina Fachel (org.). Corpo e significado. Porto Alegre: Editora da UFRGS, 1995. p. 139-151.

ANJOS, José Carlos Gomes dos; ORO, Ari Pedro. Festa de Nossa Senhora dos Navegantes em Porto Alegre: sincretismo entre Maria e Iemanjá. Porto Alegre: Secretaria Municipal de Cultura, 2009.

ÁVILA, Carla Silva. A princesa batuqueira: etnografia sobre a interface entre o movimento negro e as religióes de matriz africana em Pelotas. 2011. Dissertação (Mestrado em Ciências Sociais) - Universidade Federal de Pelotas, Pelotas, 2011.

BARBOSA NETO, Edgar Rodrigues. A máquina do mundo: variações sobre o politeísmo em coletivos afro-brasileiros. 2012. Tese (Doutorado em Antropologia Social) - Museu Nacional, Universidade Federal do Rio de Janeiro, Rio de Janeiro, 2012.

BRITO, Lucas Gonçalves. A vibração dos corpos: notas sobre uma teoria umbandista do intercâmbio mediúnico-energético. Religião \& Sociedade, Rio de Janeiro, v. 37, n. 3, p. 173-197, set./dez. 2017.

CABRERA, Lydia. A mata. São Paulo: EDUSP, 2012. 
DANOWSKI, Déborah; VIVEIROS DE CASTRO, Eduardo. Há mundo por vir? Ensaio sobre os medos e os fins. Desterro [Florianópolis]: Cultura e Barbárie: Instituto Socioambiental, 2014.

DELEUZE, Gilles. Lógica do sentido. São Paulo: Perspectiva, 2011.

DELEUZE, Gilles; GUATTARI, Félix. Mil platôs: capitalismo e esquizofrenia. São Paulo: Editora 34, 2007. v. 4.

GIUMBELLI, Emerson. Zélio de Moraes e as origens da umbanda no Rio de Janeiro. In: SILVA, Vagner G. da (org.). Caminhos da alma. Sáo Paulo: Selo Negro, 2002. p. 183-217. (Memória Afro-brasileira, 1).

ORO, Ari Pedro (org.). As religióes afro-brasileiras do Rio Grande do Sul. Porto Alegre: Editora da UFRGS, 1994.

PEIXOTO, Norberto. Umbanda pé no chão: um guia de estudos da Umbanda. Limeira: Editora do Conhecimento, 2008. v. 1.

RAMOS, João Daniel Dorneles. O cruzamento das linhas: aprontamento e cosmopolítica entre umbandistas em Mostardas, Rio Grande do Sul. 2015. Tese (Doutorado em Antropologia Social) - Universidade Federal do Rio Grande do Sul, Porto Alegre, 2015a.

RAMOS, João Daniel Dorneles. Quilombolas de Beco dos Colodianos: identidade, diferença e territorialidades. Curitiba: Appris, 2015b.

RAMOS, João Daniel Dorneles. A religiáo é como uma medicina: aprontamento, cosmopolítica e cura entre umbandistas em Mostardas, Rio Grande do Sul. In: ANDRADE, João Tadeu de; MELLO, Márcio Luiz; HOLANDA, Violeta Maria de Siqueira (org.). Saúde e cultura: diversidades terapêuticas e religiosas. Fortaleza: EdUECE, 2015c.

RAMOS, João Daniel Dorneles. A (cosmo)lógica das relaçóes humano-animais nas religiốes afro-brasileiras. Iluminuras, Porto Alegre, v. 17, n. 42, p. 166-189, 2016. 
SPINELLI, Miguel. Questóes fundamentais da filosofia grega. São Paulo: Loyola, 2006.

STENGERS, Isabelle. Cosmopolitiques VII: pour en finir avec la tolérance. Paris: La Découverte, 1997.

SZTUTMAN, Renato. Natureza \& Cultura, versão americanista: um sobrevoo. Ponto Urbe, São Paulo, n. 4, 2009. Disponível em: http://journals. openedition.org/pontourbe/1468. Acesso em: 17 nov. 2018.

VANZOLINI, Marina. Daquilo que não se sabe bem o que é: a indeterminação como poder nos mundos afroindígenas. Cadernos de Campo, São Paulo, v. 23, n. 23, p. 271-285, 2014.

VIVEIROS DE CASTRO, Eduardo. Filiação intensiva e aliança demoníaca. Novos Estudos Cebrap, São Paulo, n. 77, p. 91-126, 2007.

VIVEIROS DE CASTRO, Eduardo. Os pronomes cosmológicos e o perspectivismo ameríndio. Mana, Rio de Janeiro, v. 2, n. 2, p. 115-144, 1996. ZOURABICHVILI, François. O vocabulário de Deleuze. Rio de Janeiro: Relume Dumará, 2004.

Recebido em: 11/02/2019

Aprovado em: 09/09/2019

Debates do NER, Porto Alegre, Ano i9, N. 36, P. 307-333, AGo./Dez. 20 i 9 
